\title{
Isolated Idiopathic Lip Abscess: A Case Report
}

\author{
İzole İdiyopatik Dudak Absesi: Olgu Sunumu
}

\author{
Mahmut Sinan Yılmaz, Mehmet Güven, Süleyman Cesur, Ali Fuat Varlı \\ T.C. Sağlık Bakanlığı Sakarya Eğitim ve Araştırma Hastanesi, Kulak Burun Boğaz Kliniği, Sakarya
}

\begin{abstract}
Isolated lip abscess which is idiopathic and without any predisposing factors such as immune deficiency or systemic disease is seen rarely. We aimed to present a case of lower lip abscess which is isolated and without any predisposing factor and discussed its etiology and treatment.
\end{abstract}

Keywords: Maxillofacial infections, Lip abscess, Staphylococcus aureus

\section{Özet}

Herhangi bir sistemik hastalık veya immun sistem bozukluğu gibi prezdisozan faktör olmaksızın idiyopatik olarak ortaya çıkan izole dudak absesi nadiren görülür. Bu yazıda herhangi bir predispozan faktör olmadan gelişen izole alt dudak absesi olgusu sunularak hastalığın etiyolojisi ve tedavisi tartışıldı.

Anahtar Kelimeler: Maxillofasiyal enfeksiyonlar, Dudak absesi, Staphylococcus aureus

Başvuru Tarihi: 20.02.2011 Kabul Tarihi: 26.03.2011

\section{Introduction}

Despite the availability of potent new antimicrobial agents for the treatment of bacterial infections, cellulitis and abscess of the facial spaces of the head and neck still occurs. Maxillofacial infections and abscess are generally involved with odontogenic, dermatologic, paranasal sinus infections and trauma. ${ }^{1}$ The common etiologic organisms are Staphylococcus species or beta-hemolytic Streptococcus. Gram-positive aerobic pathogens, Haemophilus influenza, anaerobic pathogens may also cause these infections. ${ }^{1-3}$ Pathogen of the infection that causes facial abscess vary by location and source of the infection. ${ }^{4}$ The classic signs of maxillofacial infections are pain, swelling, fever, dysphagia and dehydration. Maxillofacial abscess is seen generally in submandibular, sublingual, submental and buccal spaces. $^{1}$
The lips surround the entrance to the oral cavity. They function to provide competence to the oral cavity during mastication and at rest. From superficial to deep, the layers of the upper and lower lips include the epidermis, subcutaneous tissue, orbicularis oris muscle fibers, and mucosa. Because there is no potential space in the layer of the lips, isolated lip abscess without predisposing factors like odontogenic or dermatologic infections, trauma and foreign body reaction such as piercing is extremely rare. ${ }^{6}$ In this report we present a case with isolated lower lip abscess which is idiopathic and without any predisposing factors such as immune deficiency or systemic disease.

\section{Case-Report}

A 74 years old woman admitted to our clinic with 5 days history of pain and swelling of the lower lip. There were 
no histories of trauma, insect bite, dermatologic infection or foreign body reaction like piercing. She had total dental prosthesis and no odontogenic infection symptoms or tenderness. Physical examination revealed very swollen, erythematous and sensitive lip, but review of systems and examination findings were otherwise unremarkable (Figure 1). She had not systemic diseases except hypertension. On presentation, her temperature was $38,3^{\circ} \mathrm{C}$ and she was tachycardic. There were no palpable cervical lymph nodes. The peripheral white blood cell count was 18,400 cells per $\mathrm{mm}^{3}$, with $63 \%$ segmented neutrophils. Human immunodeficiency virus serology was negative. The patient was interned and received on intravenous ampicillin and sulbactam 3 gram per day for empiric antimicrobial coverage.

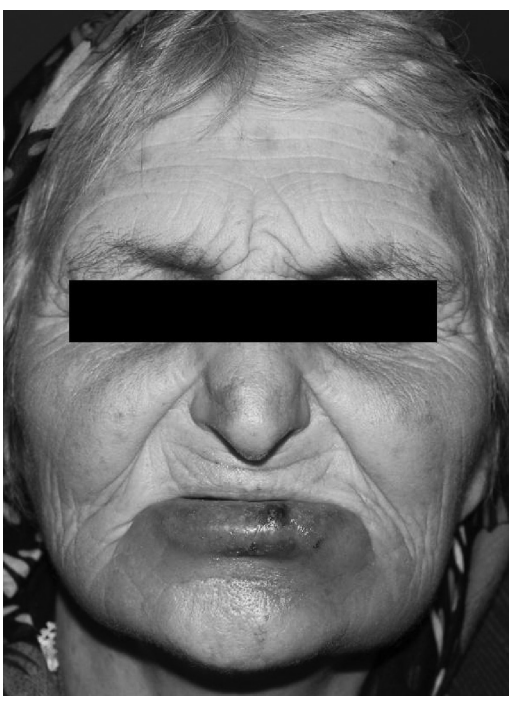

Figure 1:

Before the treatment

On second day of the hospitalization, when abscess became fluctuant, it was drained surgically. In the example taken from the purulent material Staphylococcus aureus grew. Lip swelling decreased on the fifth day of treatment (Figure 2). Body temperature came to normal and the peripheral white blood cell count decreased to 9000 cells per $\mathrm{mm}^{3}$. The patient was discharged on the sixth day without any complaint.

\section{Discussion}

Maxillofacial space infections are common presentations in maxillofacial clinics even in the post-antibiotic era. The- se infections often place the oral and maxillofacial surgeon in situations where timely decisions have to be made. These decisions can be life-saving. Maxillofacial region infections can be easily treated usually, but sometimes may be life-threatening. For management of maxillofacial infections, etiology of the infection, location of the abscess, the nature of the surgical and airway management, microbiology of the infection must be evaluated. If these infections are not treated properly, they can cause fatal complications like sepsis, pneumonia and osteomyelitis. 5,6

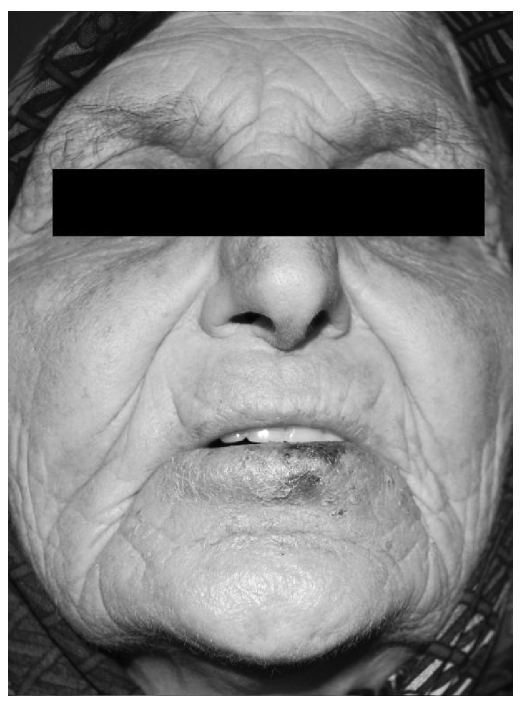

Figure 2:

After the treatment

Maxillofacial infections are usualy caused by sinus, dermatologic and odontogenic infections or trauma. ${ }^{1,2,4}$ But sometimes origins of the infections remain unclear, just like the case we reported. In our case there were no primary infections leading to this abscess. Neither trauma nor insect bite detected. In the literature lip abscesses, caused by piercing and silicone which is used for lip augmentation, were reported. ${ }^{6,7}$ They occured because of foreign body reaction. As a form of maxillofacial infections, isolated lip abscess is seen rarely. Submandibuler, sublingual, submental, buccal, odontogenic, masseteric and orbital spaces' abscess are more common.

A lot of organisms can cause infections in these regions. But Staphylococci, Haemophilus species and Streptococcal strains among others are commonly involved. Anaerobic coverage might also be selected if a dental etiology is suspected. ${ }^{1,4,5,8}$ In our case, in the culture of the purulent 
drainage Staphylococcus aureus grew. Staphylococcus aureus infections in the maxillofacial region are likely to be associated with a known portal of entry, but this is not always the case just like we reported. Its virulence and potential for serious and life-threatening infections should not be underestimated. Because of this reason, prior to culture and sensitivity results, empirical antibiotic treatment must be chosen to target those organism known to be more frequently infectious in this region. ${ }^{3,6}$ Therefore we gave to our patient intravenous ampicillin and sulbactam as empirical antibiotic therapy before the result of culture. Infections in these regions have classically been treated with penicillins, but resistant organisms have developed due to its long and widespread use. Although medication of penicillins if complication of the infection like sepsis, pneumonia, endocarditis occurs other antibiotics including clindamycin, quinolones, vancomycin should be thought. $2,6,8$

Sometimes antibiotherapy alone may not be enough for the treatment of abscess in this region. In this case surgical drainage of the abscess must be considered. Drainage

\section{References}

1. Dodson TB, Perrot DH, Kaban LB. Pediatric maxillofacial infections: a retrospective study of 113 patients. J Oral Maxillofac Surg 1989;47:327-30

2. Rao DD, Desai A, Kulkarni RD, et al. Comparison of maxillofacial space infection in diabetic and nondiabetic patients. Oral Surg Oral Med Oral Pathol Oral Radiol Endod 2010;110:7-12.

3. Geneus PM, Brooks JH. Staphylococcus aureus cellulitis: an unusual presentation. Clin Pediatr 1994;33:319-20.

4. Scutari P Jr, Dodson TB. Epidemiologic review of pediatric and adult maxillofacial infections in hospitalized patients. Oral Surg Oral Med Oral Pathol Oral Radiol Endod 1996;81:270-4

5. Krishnan V, Johnson JV, Helfrick JF. Management of maxillofacial infections: a review of 50 cases. J Oral Maxillofac Surg 1993;51:868-73.

6. Bruno GJ, Bruno JM, Miyake AA. Community-aquired methicillin- also shortens the duration of the treatment of abscess. A concept that has often been adhered to is that drainage should only be performed when fluctuance is present to produce laudable pus. ${ }^{9}$ Surgical intervention in the cellulitic phase was thought to be undesirable as it would result in further spread of the infection. Contrary to this thought in some reports it is suggested that decompression of the indurations, debridement of the necrotic tissue and the elimination of dead space during cellulitic phase, combined with appropriate antibiotic therapy has resulted in rapid resolution of infections. ${ }^{10}$

The classic signs of maxillofacial infections include pain, swelling, fever, dysphagia and dehydration. The goals of management should be to correct these conditions. Maxillofacial infections can be easily treated with appropriate antibiotic therapy and combined surgical drainage. Among the maxillofacial infections and abscess isolated and idiopathic lip abscess is seen rarely. But we must be awake because of its serious complications. If it is managed with fast and proper therapy medical and surgical fatal complications can be prevented.

resistant staphylococcus aureus infections with fatal necrotizing pneumonia from lip abscess: a case report. J Oral Maxillofac Surg 2007;65:2350-3

7. Schmidt-Westhausen AM, Frege J, Reichart PA. Abscess formation after lip augmentation with silicone: case report. Int J Oral Maxillofac Surg 2004;33:198-200.

8. Warnke PH, Becker ST, at al. Penicillin compared with other advanced broad spectrum antibiotics regarding antibacterial activity against oral pathogens isolated from odontogenic abscesses. J Cranio-Maxillofac Surg 2008;36:462-7.

9. Topazian RG, Goldberg MH. Oral and maxillofacial infections. 2nd ed. Philadelphia: Saunders, 1987.

10. Flynn TR. Odontogenic infections. Oral and Maxillofac Surg Clin North Am 1991;3:311. 